\title{
Spatial distribution and assemblage structure of macrobenthos in a tidal creek in relation to industrial activities
}

\author{
${ }^{1 *}$ N. Mooraki; ${ }^{2}$ A. Esmaeli Sari; ${ }^{3}$ M. Soltani; ${ }^{4}$ T. Valinassab \\ ${ }^{1}$ Department of Natural Resources, Science and Research Branch, Islamic Azad University, Tehran, Iran \\ ${ }^{2}$ Department of Fisheries, Faculty of Natural Resources and Marine Science, Tarbiat Modares University, \\ Noor, Iran \\ ${ }^{3}$ Department of Aquatic Animal Health, Faculty of Veterinary Medicine, University of Tehran, Tehran, Iran \\ ${ }^{4}$ Iranian Fisheries Research Organization, P.O. Box: 14155-6116, Tehran, Iran
}

Received 13 December 2008; $\quad$ revised 5 June 2009; $\quad$ accepted 3 August 2009; $\quad$ available online 1 September 2009

\begin{abstract}
The impact of petrochemical special economic zone activities on the health status of Jafari Creek was studied by assessing the changes in macroinvertebrate assemblages in nine sites during September 2006- January 2008. The relationship between spatial pattern of macroinvertebrate assemblages and ambient factors (i.e. water temperature, salinity, $\mathrm{pH}$, dissolved oxygen, sediment grain size distribution, sediment organic content, heavy metals contents) was measured. Background enrichment indices, contamination factor and contamination degree, were used to assess the health status in the study area based on nickel, lead, cadmium and mercury contents of the sediments. The macrobenthic communities had a low diversity and were dominated by opportunistic taxa. The BIO-ENV analysis identified salinity, dissolved oxygen, $\mathrm{pH}$ and silt/clay content of sediments as the major environmental variables influencing the infaunal pattern. This suggests that management should attempt to ensure minimal disturbance to environmental variables underlying the spatial variation in macroinvertebrate assemblages. Background enrichment indices showed that the health of Jafari Creek has declined over time due to the constant discharge of heavy metals to the Creek system. These indices also identified a significant degree of pollution in the study area. The decrease in the ecological potential of Jafari Creek was best highlighted by the alteration in macrobenthic assemblages.
\end{abstract}

Keyword: Anthropogenic activities; Background enrichment indices; Environmental variables; Pollution detection; Heavy metals; Variation of soft bottom macrofauna communities

\section{INTRODUCTION}

Estuaries are important marine ecosystems by maintaining the coastal biota, being one of the highly productive systems and serving as breeding and nursery grounds for a diverse array of organisms (Dobson and Frid, 1998; Currier and Small, 2005; Karbassi et al., 2008). Urbanization and industrialization have imposed a heavy burden on estuarine ecosystems. The health of estuaries has largely declined as a result of direct discharge of waste from adjacent industrial and municipal sources and urban run-off (Kennish, 1991). A wide variety of environmental monitoring programs have been conducted to evaluate the degree of alteration occurring in estuaries. Earlier studies have shown that the distributional patterns of macrobenthos are closely linked to environmental factors (Thrush, 1991; Morrisey et al., 1992; Macfarlane and Booth, 2001;

$\triangle$ *Corresponding Author Email: nargess_mooraki@yahoo.com Tel.: +9821 8890 1411; Fax: +9821 88926795
Morrisey et al., 2003; Currier and Small, 2005; Nouri et al., 2008). Accordingly, the study of alterations in macrobenthic communities has been suggested as an appropriate biological indication of environmental stress (Bilyard, 1987; Ysebaert and Herman, 2002; Ysebaert et al., 2002; Morrisey et al., 2003). Numerous studies have demonstrated links between spatial variation in the environment and/or habitats and spatial variation in the benthic community in aquatic systems. For example, Gaston and Nasci (1988), Gray et al. (1988) and Raut et al. (2005) found significant correlations among abiotic factors such as salinity, $\mathrm{pH}$, sediment characteristics and dissolved oxygen with distributional patterns of macrobenthic communities. Earlier studies have shown that benthic assemblages may be largely affected by anthropogenic activities. For example, Inglis and Kross (2000) found significant alteration in macroinvertebrate assemblages of an 
estuarine system subjected to urbanization. Accordingly, Mucha et al. (2003) and Courtenay et al. (2005) found considerable changes in macrofauna assemblages in Douro estuary (Portugal) and Sydney estuaries (Australia), respectively, due to anthropogenic activities. The conclusions from all of these studies have been that the proper assessment of sediment contamination and ambient factors in estuaries and their effects on macrobenthos assemblages and composition is a beneficial method for evaluating the health of these ecosystems. During the last two decades or so, Mahshahr Creeks in Musa Bay has become one of the main economic assets of the north-west coast of the Persian Gulf, serving a variety of industrial activities (Fig. 1). Despite some early endeavors which generally focused on identifying estuarine macroinvertebrates to the higher taxonomic levels (e.g. Nabavy, 1992; Parsamanesh, 1994), the subtropical tidal communities, the structure of macrobenthic assemblages and their spatial variation in Mahshahr Creeks have largely remained unknown. This is especially the case in Jafari Creek which has been subjected to anthropogenic activities since 1993. In this year, the construction of petrochemical special economic zone (PETZONE) in an area of about $17 \mathrm{Km}^{2}$, followed by the inception of petrochemical activities of the complexes situated in this zone, affected some parts of Mahshahr Creeks ecosystem. One of the worst affected areas is Jafari Creek. In this regard, to assess the health status of Jafari Creek, the present study based on three main objectives, has been conducted in this area. The primary objectives of the present study were to explore the community structure and spatial pattern of benthic macroinvertebrates in Jafari Creek, as well as exploring the relationship between the spatial pattern of macroinvertebrates with environmental variables (i.e. water temperature, salinity, $\mathrm{pH}$, dissolved oxygen, sediment particle size distribution, sediment organic matter, heavy metals content). A further objective was to use Background Enrichment indices to assess the extent to which the health of Jafari Creek has declined due to the inputs of heavy metals. In this respect, the macrobenthos assemblages and environmental variables were sampled in Jafari Creek from September 2006 to January 2008.

\section{MATERIALS AND METHODS}

This study was undertaken at Jafari Creek located in Mahshahr Creeks, which is connected to the Musa
Bay, north-west of the Persian Gulf(Fig.1). Jafari Creek, with an area of about $5.1 \mathrm{~km}^{2}$, is a subtropical tidal creek with tidal range of $0.8-5.1 \mathrm{~m}$ surrounded by a vast muddy expanse (Niyyati and Maraghei, 2002). This Creek receives irregular fresh water following the seasonal precipitation of about $100-300 \mathrm{~mm} /$ y occurring mainly from November to February (Niyyati and Maraghei, 2002). In 1993, an area of about $1.22 \mathrm{~km}^{2}$ of the Jafari Creek was isolated and $0.8 \mathrm{~km}^{2}$ drained off for construction of PETZONE. The remaining area $\left(0.41 \mathrm{~km}^{2}\right)$ is used as sewage and post treatment waste receptor. Sewage and post treatment waste runs into the main body of the Creek through a connective canal which is opened only during low tide (Fig. 1). Samples (i.e. macroinvertebrates and environmental variables) in submerged depositional substrates of Jafari Creek were collected from nine sites. The Sites were selected in a way to encompass the entire area with the similar characteristics on the basis of general appearance and sediment particle size distribution. Moreover, the choice of sites was also influenced by accessibility, logistics and safety considerations. Sites 1 and 2 were placed inside the PETZONE boundaries with 1.85 and $1 \mathrm{~km}$ distance away from the connective canal. Sites 3, 4 and 8 were situated respectively $0.8,1.5$, and $1.25 \mathrm{Km}$ from the connective canal, out of the PETZONE boundaries. Sites 5, 6, 7 and 9 were located out of the PETZONE far from connective canal. The distance of the aforementioned sites is respectively 2, 3.1, 3.25 and finally $3.5 \mathrm{Km}$ away from the mentioned canal (Fig. 1). Samplings were performed from September 2006 to January 2008 every 50 days and conducted within $2 \mathrm{~h}$ after high tide. Sediment samples were taken using an Eckman grab. The sampler collects a piece of sediment with an area of $225 \mathrm{~cm}^{2}$, a thickness of 5-15 cm weighing about 600-2000 g. The number of replications of sediment samples collected for biota analysis was determined by a pilot study that revealed three replications provided means with acceptable precision (i.e. standard error/mean $\leq 0.1$ (Andrew and Mapstone, 1987)) for species richness. Accordingly, three sediment samples were taken from each of the nine sites for macroinvertebrate analyses. Collected sediments were sieved through a $0.5 \mathrm{~mm}$ mesh and retained macroinvertebrates were preserved in $7 \%$ formalin buffered in sea water, followed by $70 \%$ ethanol with rosebengal for sorting. Samples were sorted under a dissecting microscope using $16 \times$ magnification and all macroinvertebrates identified to the lowest possible 


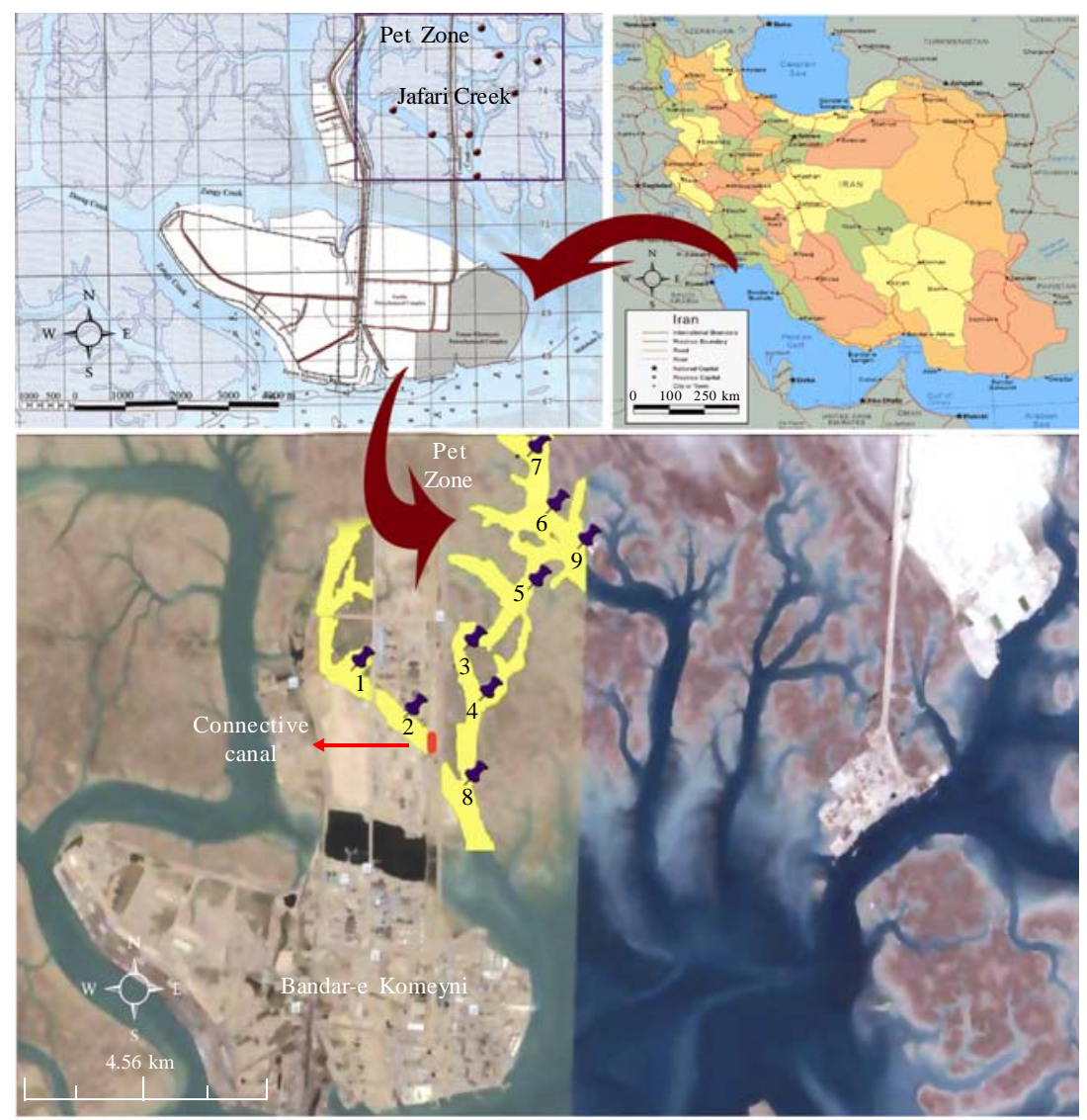

Fig. 1: (a) The location of Mahshahr Creeks, (b) the location of Musa Bay, Jafari Creek and Petrochemical Special Economic Zone (PETZONE) and (c) the location of the sampling sites and connective canal in Jafari Creek and PETZONE, northwest of the Persian Gulf

taxonomic level, often to family level, by use of systematic and classification keys (Ponder et al., 2000; e.g. Martin and Davis, 2001; Todd, 2001; Glasby and Fauchald, 2002). Previous studies have shown this level of taxonomic resolution to be cost-effective and sufficient for detecting effects associated with a variety of anthropogenic disturbances (Warwick, 1988; James et al., 1995; Chapman, 1998). Three additional sediment samples were collected from each of nine sites and each sample was divided into three parts for sediment particle size distribution, total organic matter and heavy metals (i.e. nickel, lead, cadmium and mercury) content analyses. In order to determine sediment particle size distribution, the first part of each sample was dried at $70{ }^{\circ} \mathrm{C}$ for $48 \mathrm{~h}$ and sieved through a nested series of sieves. The sediments were partitioned into gravel \% (2.0 mm), sand \% (0.063 mm) and silt/clay \% $(<0.063$ mm) (Folk, 1968). The second part of each sample was first dried at $70{ }^{\circ} \mathrm{C}$ for $48 \mathrm{~h}$ and then combusted at 550 ${ }^{\circ} \mathrm{C}$ for 60 min to determine total organic matter content through weight loss (ROPME, 1999). The third part was used for assessing the concentrations of four elements (i.e. $\mathrm{Ni}, \mathrm{Pb}, \mathrm{Cd}$ and $\mathrm{Hg}$ ), in which the sediments were dried at $70{ }^{\circ} \mathrm{C}$ for $48 \mathrm{~h}$, homogenized and sieved through a $50 \mu \mathrm{m}$ screen and $1 \mathrm{~g}$ of sample, less than 50 $\mu \mathrm{m}$ in fraction size, was digested with Aqua-regia (HNO3: $\mathrm{HCl}$ ) and HF (Loring and Rantala, 1992). The samples were analyzed separately using mercury analyzer for $\mathrm{Hg}$ and atomic absorption spectrophotometer for the other elements. The Merck standards were used for the calibration curves. The measured concentrations of elements were determined on dry weight basis in $\mathrm{mg} / \mathrm{kg}$ (ppm). Water temperature $\left({ }^{\circ} \mathrm{C}\right)$, salinity (psu), $\mathrm{pH}$ and dissolved oxygen $(\mathrm{mg} / \mathrm{L})$ were measured at each nine 
sites during the sampling procedure using WTW conductimeter. Data analyses were undertaken using PRIMER version 6 (Plymouth Marine Laboratories, Clarke and Warwick, 2001) and SPSS version 13. The hypothesis states that, the spatial patterns in the number of species were divided with respect to industrial activities was explored by measuring the relative BrayCurtis similarity of assemblages at the study area and was depicted using non-metric multidimensional scaling (nMDS). The hypothesis that macroinvertebrate assemblages differ among sites was tested using analysis of similarity (ANOSIM) to determine whether any observed differences in macroinvertebrate assemblages were statistically significant. The contribution of specific taxa to the differences in macroinvertebrate assemblages among sites was examined using SIMPER analysis. The Mean abundance of macroinvertebrates was $4^{\text {th }}$ root transformed to reduce the influence of very abundant species. The relative Euclidean dissimilarity of sites based on their environmental variables was delineated using nMDS of $\log (\mathrm{x}+1)$ transformed environmental data. The objective as to, which environmental variable and to what extent was affected the composition of macroinvertebrate assemblages and their spatial pattern, was evaluated by BIOENV routine, which is based on weighted Spearman rank correlations between the similarity matrices of the two data sets. The total abundance, taxonomic richness, and Shannon-Wiener diversity index were measured using diverse routine in PRIMER. Differences in environmental variables among sites were tested using the non-parametric Kruscal-Wallis test in SPSS version 13. To assess the extent to which the health of Jafari Creek has declined due to inputs of heavy metals, Background Enrichment indices, including Contamination factor and Contamination degree, were calculated for the study area. The contamination factor $\left(\mathrm{C}_{\mathrm{f}}\right)$ is defined as the contamination of a given toxic substance in a basin as below (Hakanson, 1980; Kwon and Lee, 1998):

$$
\mathrm{C}_{\mathrm{f}}=\mathrm{C}_{\mathrm{e}} / \mathrm{C}_{\mathrm{pi}}
$$

Where, $\mathrm{C}_{\mathrm{e}}$ is concentration of element in sediment samples and $C_{\text {pi }}$ is preindustrial reference value (natural reference) for the element. In this regard, $\mathrm{C}_{\mathrm{f}}<1$ represents a low contamination factor (indicating low sediment contamination of the studied factor), $1 \mathrm{~d}^{\text {" }} \mathrm{C}_{\mathrm{f}}<3$ represents a moderate contamination factor, $3 \mathrm{~d}^{\prime} \mathrm{C}_{\mathrm{f}}<6$ represents a considerable contamination factor and $\mathrm{C}_{\mathrm{f}} \geq 6$ represents a very high contamination factor (Hakanson, 1980; Asku et al., 1997; Nasr et al., 2006; Dehgan et al., 2008). The degree of contamination $\left(\mathrm{C}_{\mathrm{d}}\right)$ is defined as the sum of all contamination factors for various heavy metals (Hakanson, 1980; Kwon and Lee, 1998):

$\mathrm{C}_{\mathrm{d}}=\Sigma^{\mathrm{n}} \mathrm{C}_{\mathrm{f}}$

In this regard, $\mathrm{C}_{\mathrm{d}}<7$ represents a low degree of contamination, $7 \mathrm{~d}$ " $\mathrm{C}_{\mathrm{d}}<14$ represents a moderate degree of contamination, $14 \mathrm{~d}^{\prime \prime} \mathrm{C}_{\mathrm{d}}<28$ represents a considerable degree of contamination and $C_{d} \geq 28$ represents a very high degree of contamination indicating serious anthropogenic pollution (Hakanson, 1980; Asku et al., 1997; Nasr et al., 2006; Dehgan et al., 2008). The mean concentration of each heavy metal from all sites was compared with acceptable quantities of heavy metals for unpolluted areas suggested by NOAA (National Oceanic and Atmospheric Administration) and ISQGs (Interim Sediment Quality Guidelines) (Long et al., 1995; Buchman, 1999; CCME, 1999).

\section{RESULTS AND DISCUSSION}

A total of 227745 macroinvertebrates were sampled, representing three phyla, five classes and 32 families. Polychaetes were the most diverse class with 16 families mainly dominated by Glyceridae followed by Cossuridae, Eunicidae, Nereidae and Onuphidae (Table 1). Polychaetes comprised $62.12 \%$ of the total number of individuals, followed by bivalvia (18.00\%), crustaceans (12.20\%) and gastropoda (7.73\%). A significant difference was found in invertebrate assemblages among sites, as in sites one and two, situated in the surrounding area, no macroinvertebrate individual was found during the sampling period and the other seven sites showed a variable composition of macrobenthic communities (Table2). The sites which were situated out of the PETZONE boundaries (i.e. sites 3 to 9 ) were dominated by polychaetes followed by molluscs. Faunal assemblages in sites 8 and 9 were respectively distinguished by large densities of Veneridae and Postamididae (molluscs) followed by Tanaidaceae (crustacean) and Eunicidae (polychaetes), whereas the remaining five sites were dominated by polychaetes (Table 3). The marked variation in macrobenthos abundance among sites was delineated clearly with differences between sites located in PETZONE boundaries and those outside. These results are supported by nMDS (Fig. 2). Such a break down in spatial pattern of macrobenthos is largely controlled by abundant number of polychaetes and few numbers of molluscs 
Table 1: Mean number of ind. $/ \mathrm{m}^{2}$ of each of the taxonomic groups in Jafari Creek, north-west of Persian Gulf

\begin{tabular}{|c|c|c|}
\hline Phylum & Class & Mean number of taxa \\
\hline \multirow[t]{16}{*}{ Annelidae } & Polychaeta & Aphroditidae, 418 \\
\hline & & Capitelidae, 35 \\
\hline & & Cossuridae, 3521 \\
\hline & & Centrodrilidae, 2 \\
\hline & & Eunicidae, 2929 \\
\hline & & Glyceridae, 4526 \\
\hline & & Hesionidae, 7 \\
\hline & & Lumbrinereidae, 81 \\
\hline & & Nereidae, 2105 \\
\hline & & Nephtyidae, 239 \\
\hline & & Onuphidae, 1390 \\
\hline & & Pectinaridae, 30 \\
\hline & & Serpulidae, 868 \\
\hline & & Spionidae, 69 \\
\hline & & Sternapsidae, 38 \\
\hline & & Terbelidae, 10 \\
\hline \multirow[t]{11}{*}{ Mollusca } & Bivalvia & Ostreidae, 163 \\
\hline & & Solenidae, 209 \\
\hline & & Veneridae, 1009 \\
\hline & & Yoldiidae, 1659 \\
\hline & & Larva, 1196 \\
\hline & Gastropoda & Barleeidae, 376 \\
\hline & & Columellidae,71 \\
\hline & & Planorbidae, 20 \\
\hline & & Postamididae, 1339 \\
\hline & & Truncatellidae, 7 \\
\hline & & Turbinidae, 10 \\
\hline \multirow[t]{10}{*}{ Arthropoda } & Malacostraca & Ampithoidae, 752 \\
\hline & Isopoda (Order) & Alpheidae, 38 \\
\hline & Tanaidacea (Order) & Gonodactylidae, 41 \\
\hline & Cumaceae(Order) & Grapsidae, 632 \\
\hline & Ostracoda & Ocypodidae, 33 \\
\hline & & Isopoda, 345 \\
\hline & Maxilliopoda & Tanaidacea, 876 \\
\hline & Cirripedi (Infraclass) & Cumaceae, 242 \\
\hline & & Ostracoda, 12 \\
\hline & & Cirripedi, 12 \\
\hline
\end{tabular}

which are also indicated by their contribution percentage as it shown in Table 3. Average density, species richness, Shannon-Wiener diversity and evenness indices were accounted for $2530.5 \mathrm{ind} / \mathrm{m}^{2}$ (ranging 0-49751 ind $/ \mathrm{m}^{2}$ ), 1.35 $\pm 0.63,1.44 \pm 0.38$ and $0.70 \pm 0.39$, respectively in the study area. The highest density, species richness, evenness and Shannon- Wiener indices were found in sites 6, 9, 5 and 9, respectively (Fig. 3). The outer sites possessed high density and species richness of macroinvertebrates along with Shannon-Wiener diversity and evenness indices. Water salinity was significantly variable within the Creek, with hyper-saline condition in sites 1 and 2 with maximum of 345 and 318(Table 4). Water temperature was not significantly different among outer sites, but showed a significant difference between sites located in PETZONE and the outer sites (Table 4).
Table 2: Summery of one-way ANOSIM of total macroinvertebrate abundance comparison between outer sites in Jafari Creek, north-west of Persian Gulf

\begin{tabular}{ll}
\hline Comparisons & Pairwise R \\
\hline Site 3 vs Site 4 & -0.00 \\
Site 3 vs Site 5 & 0.02 \\
Site 3 vs Site 6 & 0.01 \\
Site 3 vs Site 7 & 0.02 \\
Site 3 vs Site 8 & $0.00 *$ \\
Site 3 vs Site 9 & $0.00 *$ \\
Site 4 vs Site 5 & 0.07 \\
Site 4 vs Site 6 & 0.03 \\
Site 4 vs Site 7 & 0.01 \\
Site 4 vs Site 8 & $0.00 *$ \\
Site 4 vs Site 9 & $0.00 *$ \\
Site 5 vs Site 6 & 0.01 \\
Site 5 vs Site 7 & 0.02 \\
Site 5 vs Site 8 & $0.00 *$ \\
Site 5 vs Site 9 & $0.00 *$ \\
Site 6 vs Site 7 & 0.09 \\
Site 6 vs Site 8 & $0.00 *$ \\
Site 6 vs Site 9 & $0.00 *$ \\
Site 7 vs Site 8 & $0.00 *$ \\
Site 7 vs Site 9 & $0.00 *$ \\
Site 8 vs Site 9 & 0.01 \\
\hline Significant level $P<0.001$ (Global R=0.386, P = 0.001$)$ &
\end{tabular}

* Significant level $P<0.001$ (Global $\mathrm{R}=0.386, P=0.001$ )

Dissolved oxygen was significantly different between sites 1 and 2 and that of other sites. Anoxia condition was measured at site one (Table 4). The $\mathrm{pH}$ was significantly different among sites located outside of the PETZONE (Table 4). Total organic content in sediment showed a high variability among the outer sites (Table 4). Sediments were generally dominated by medium to very fine particles and did not show significant differences among the outer sites $(P>0.85)$. In sites 1 and 2 , the substrate was entirely dominated by crystallized salts and petrochemical residuals. The substrate in sites 3, 4 and to some extent in site 8 located near the PETZONE were composed of fine sand and silt especially in site three which was dominated by silt (Table 5). These results are supported by non metric multidimensional scaling ordination (nMDS) (Fig. 4). The BIOENV results showed that variation in the macroinvertebrate assemblages were correlated with salinity, dissolved oxygen, $\mathrm{pH}$ and silt/ clay content of sediments (BIOENV, $p_{w}=0.68$ ). The highest mean concentrations of cadmium (2.84 \pm 0.25 ppm) and lead (7.69 $\pm 0.28 \mathrm{ppm})$ were recorded in site two, and the highest mean value for mercury $(1.09 \pm 0.07$ ppm) and nickel (63.6 $\pm 2.52 \mathrm{ppm})$ were found at site 3 (Fig.5). The results of the Kruskal-Wallis test showed significant difference only in lead concentration between sites located in PETZONE (i.e. sites one and two) and those located out of the PETZONE (i.e. sites 3 to 9) 


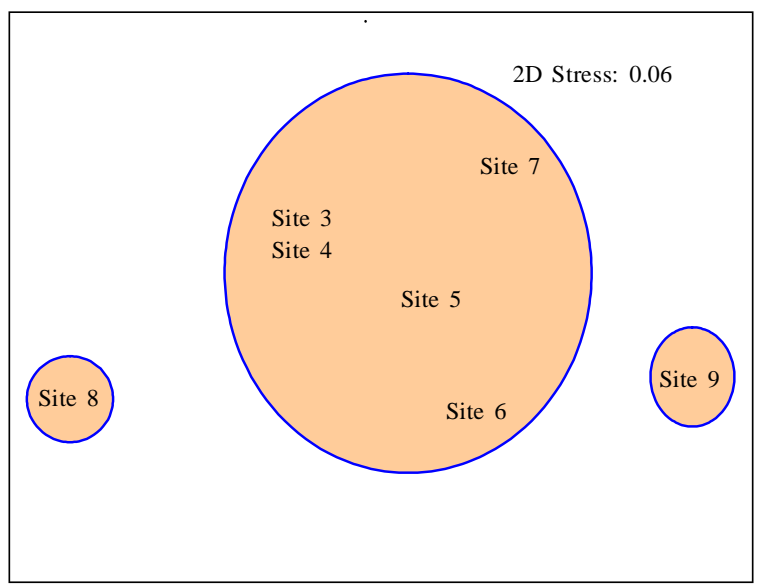

Fig. 2: nMDS ordination of macroinvertebrate assemblages over nine sites in Jafari Creek, north-west of Persian Gulf. Sites one and two were devoided from any macrobenthos individuals
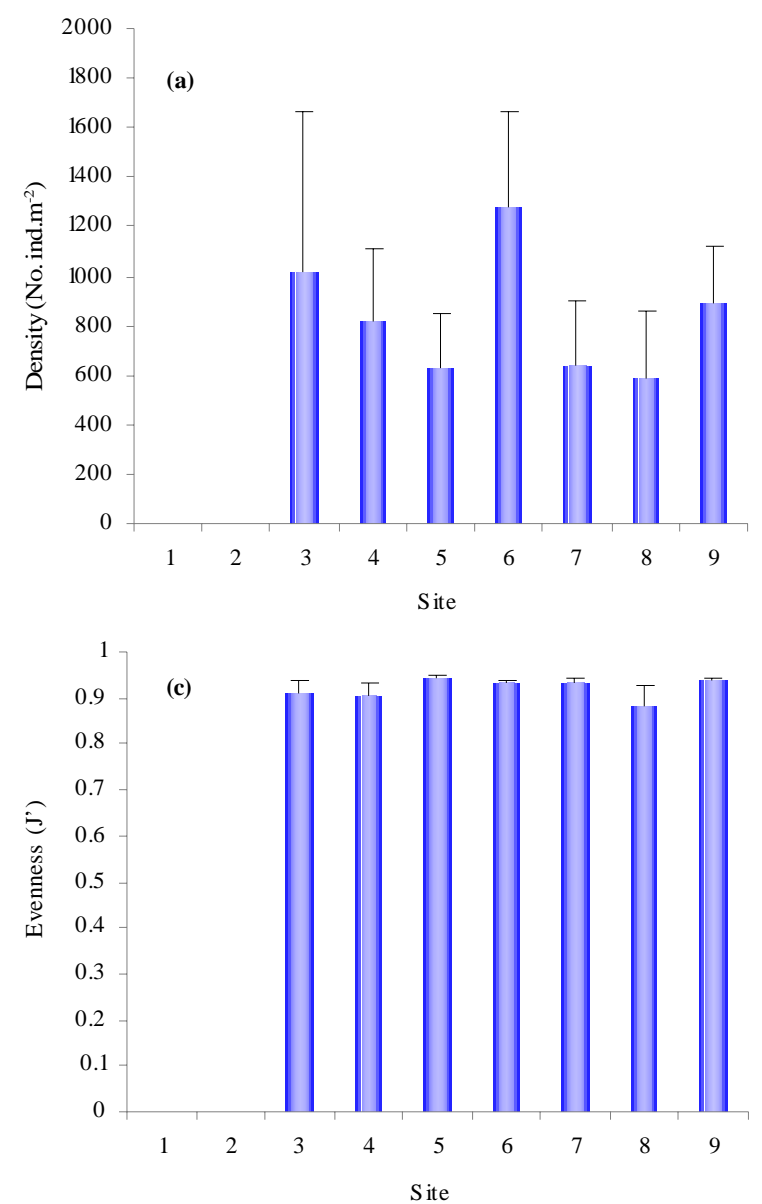

(Table 6). Mean concentrations of mercury and nickel were higher than the acceptable quantities for unpolluted areas suggested by NOAA (National Oceanic and Atmospheric Administration) and ISQGs (Interim Sediment Quality Guidelines) (Long et al., 1995; Buchman, 1999; CCME, 1999). Mean concentration of lead and cadmium were under acceptable quantities for unpolluted areas (Table 7). The contamination factor was calculated for nickel, lead, cadmium and mercury. Results showed that mercury and cadmium were respectively the most responsible elements in polluting the sediments of the study area (Table 8). This is further supported by the calculation of the contamination degree for the studied area, which shows a considerable degree of contamination which resulted from the cumulative effect of four sampled elements (Table 8). At small spatial scales, patterns of macroinvertebrate distribution have been shown to be controlled by
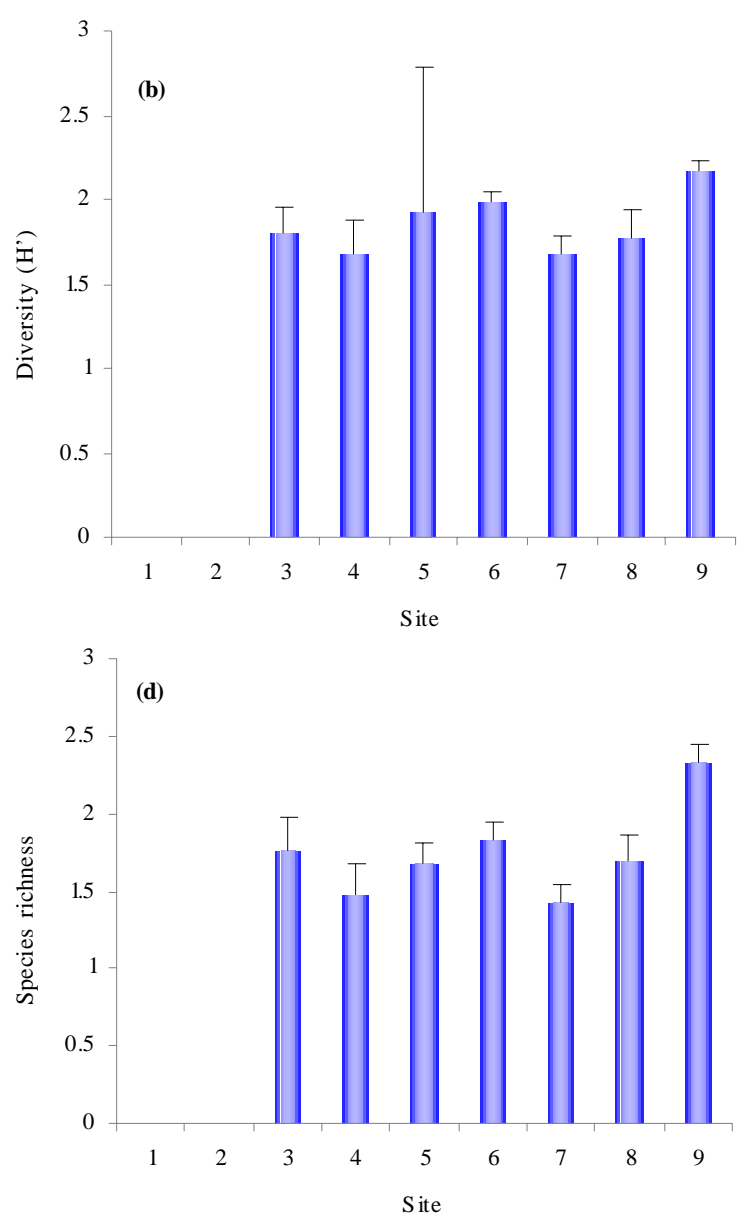

Fig. 3: Variation in ecological indices including mean density (a), Shannon -Wiener diversity ( $\mathrm{H}^{\prime}$ ) (b), evenness(c) and species richness (d) for sites located in Jafari Creek, north-west of Persian Gulf. *Error bars show standard error 
Int. J. Environ. Sci. Tech., 6 (4), 651-662, Autumn 2009

Table 3: Contribution of most influencing taxon to the average dissimilarity between the macroinvertebrate assemblages over nine sites in Jafari Creek, north-west of Persian Gulf

\begin{tabular}{|c|c|c|c|c|c|}
\hline Sites & Species & $\begin{array}{l}\text { Average abundance } \\
\text { (ind } / \mathrm{m}^{2} \text { ) }\end{array}$ & Contribution (\%) & $\begin{array}{l}\text { Cumulative } \\
\text { contribution (\%) }\end{array}$ & $\begin{array}{l}\text { Average } \\
\text { similarity }\end{array}$ \\
\hline 1 & - & 0 & 0 & 0 & 0 \\
\hline 2 & - & 0 & 0 & 0 & 0 \\
\hline \multirow[t]{4}{*}{3} & Glycerid polychaetes & 199.50 & 22.76 & 22.76 & 4.58 \\
\hline & Eunicid polychaetes & 183.10 & 19.58 & 42.34 & 3.94 \\
\hline & Cossurid polychaetes & 2531.90 & 15.42 & 57.76 & 3.11 \\
\hline & Nereid polychaetes & 191.00 & 14.54 & 72.30 & 2.93 \\
\hline \multirow[t]{4}{*}{4} & Glycerid polychaetes & 1022.90 & 39.91 & 39.91 & 9.12 \\
\hline & Eunicid polychaetes & 424.90 & 21.06 & 60.97 & 4.81 \\
\hline & Nereid polychaetes & 311.00 & 10.97 & 71.95 & 2.51 \\
\hline & Venerid bivalves & 133.70 & 7.84 & 79.79 & 1.79 \\
\hline \multirow[t]{4}{*}{5} & Glycerid polychaetes & 770.30 & 25.52 & 25.52 & 6.74 \\
\hline & Nereid polychaetes & 228.10 & 22.71 & 48.23 & 6.00 \\
\hline & Eunicid polychaetes & 223.60 & 20.96 & 69.20 & 5.54 \\
\hline & Venerid bivalves & 117.00 & 12.61 & 81.80 & 3.33 \\
\hline \multirow[t]{4}{*}{6} & Glycerid polychaetes & 1300.60 & 47.77 & 47.77 & 14.25 \\
\hline & Eunicid polychaetes & 325.90 & 14.29 & 62.06 & 4.26 \\
\hline & Nereid polychaetes & 316.90 & 8.11 & 70.17 & 2.42 \\
\hline & Amphipoidcrustaceans & 228.10 & 4.70 & 74.86 & 1.40 \\
\hline \multirow[t]{4}{*}{7} & Eunicid polychaetes & 914.00 & 35.02 & 35.02 & 8.68 \\
\hline & Glycerid polychaetes & 330.30 & 25.25 & 60.26 & 6.26 \\
\hline & Nereid polychaetes & 351.00 & 14.91 & 75.17 & 3.70 \\
\hline & Yoldiid bivalves & 195.50 & 7.31 & 82.48 & 1.81 \\
\hline \multirow[t]{4}{*}{8} & Venerid bivalves & 322.90 & 36.10 & 36.10 & 12.48 \\
\hline & Postamidid gastropods & 1054.00 & 23.15 & 59.25 & 8.00 \\
\hline & Glycerid polychaetes & 188.00 & 12.38 & 71.64 & 4.28 \\
\hline & Eunicid polychaetes & 134.60 & 9.55 & 81.19 & 3.30 \\
\hline \multirow[t]{4}{*}{9} & Eunicid polychaetes & 429.70 & 25.53 & 25.53 & 9.26 \\
\hline & Tanaidacea crustacean & 516.40 & 16.85 & 42.38 & 6.11 \\
\hline & Glycerid polychaetes & 261.60 & 12.30 & 54.68 & 4.46 \\
\hline & Isopoda crustacean & 144.40 & 8.96 & 63.64 & 3.25 \\
\hline
\end{tabular}

variation in underlying environmental variables (Barry and Dayton, 1991; Thrus et al., 1996; Inglis and Kross, 2000; Chapman, 2002; Mikac et al., 2007). In the present study, significant correlations were found between macroinvertebrate assemblages and salinity, dissolved oxygen, $\mathrm{pH}$ and silt/clay content of sediments. Human activities are likely to alter these variables which resulted in changes in taxonomic composition and variation in the abundance of individual taxa (Warwick and Clarke, 1993). This suggests that management should attempt to ensure minimal disturbance to environmental variables underlying the spatial variation in macroinvertebrate assemblages by executing careful assessment programs. The present study demonstrated that anthropogenic and industrial disturbances have exerted a significant effect on environmental factors and benthic macroinvertebrates of Jafari Creek. The most noteworthy effects on habitat have been made through: (1) reductions in total areas of inhabitable substrate available to macroinvertebrate and (2) the development of hypersaline, anoxia conditions and alteration of the characteristics of sediments especially in sites situated in PETZONE. Water quality and sediment characteristics in Jafari Creek have largely declined due to: 1) long term closure of the connective canal during high tide, 2) consequent loss of sea water intrusion, 3 ) increased salt loads in the water column caused by high evaporation and low precipitation rates and 4) long term discharge of post treatment wastes into the surrounding sites. All these alterations probably have made the substrate uninhabitable for benthic macroinvertebrates. This was indicated by the absence of macroinvertebrates in surrounding sites. In contrast, in sites located out of the PETZONE boundaries, macroinvertebrates appeared in most diverse communities, where hyper-saline, anoxia conditions and habitat loss were less severe. The ecological effects of habitat fragmentation in Jafari Creek have resulted in discontinuous nutrient and organic matter flows between adjacent habitats. Earlier study has also suggested habitat fragmentation as an effective factor for declining interchange of macrofaunal larvae within the system (Eckman, 1996). The results of this study showed that macroinvertebrate compositions in the outer sites were numerically dominated by 
Table 4: Descriptive statistics and the results of non-parametric Kruscal-Wallis test for environmental variables in Jafari Creek, north-west of Persian Gulf

\begin{tabular}{|c|c|c|c|c|c|c|}
\hline \multicolumn{3}{|c|}{$\begin{array}{l}\text { Source of variation } \\
\text { Between Surrounding and Outer Sites }\end{array}$} & \multicolumn{4}{|c|}{ Among Nine Sites } \\
\hline Factor & $\mathrm{df}$ & $\mathrm{p}$ & $\mathrm{df}$ & Chi-Square & $\mathrm{p}$ & $\begin{array}{l}\text { Mean ( } \pm \text { S.E) } \\
\text { (Max.-Min.) }\end{array}$ \\
\hline Temperature $\left({ }^{\circ} \mathrm{C}\right)$ & 1 & $0.01 *$ & 8 & 6.57 & 0.58 & $\begin{array}{l}24.35( \pm 0.67) \\
(43-14)\end{array}$ \\
\hline Salinity $^{\mathrm{a}}$ & 1 & $0.00 *$ & 8 & 55.13 & $0.00 *$ & $\begin{array}{l}72.12( \pm 7.06) \\
(345.20-39.47)\end{array}$ \\
\hline $\mathrm{pH}^{\mathrm{a}}$ & 1 & 0.10 & 8 & 25.22 & $0.00 *$ & $\begin{array}{l}7.81( \pm 0.30) \\
(8.46-6.93)\end{array}$ \\
\hline $\begin{array}{l}\text { Dissolved }^{\text {a }} \\
\text { oxygen }\end{array}$ & 1 & $0.00 *$ & 8 & 44.72 & $0.00 *$ & $\begin{array}{l}6.19( \pm 0.25) \\
(10.30-0.55)\end{array}$ \\
\hline $\begin{array}{l}\text { Total }^{\mathrm{a}} \\
\text { organic content }^{2}\end{array}$ & 1 & 0.09 & 8 & 43.04 & $0.00 *$ & $\begin{array}{l}11.62( \pm 0.41) \\
(20.24-5.10)\end{array}$ \\
\hline
\end{tabular}

* Significant level $(p<0.05)$. ${ }^{a}$ Data transformed to $\operatorname{Ln}(\mathrm{x}+1)$ before analysis of variance

Table 5: Descriptive statistics for grain-size distribution at studied stations in Jafari Creek, north-west of Persian Gulf

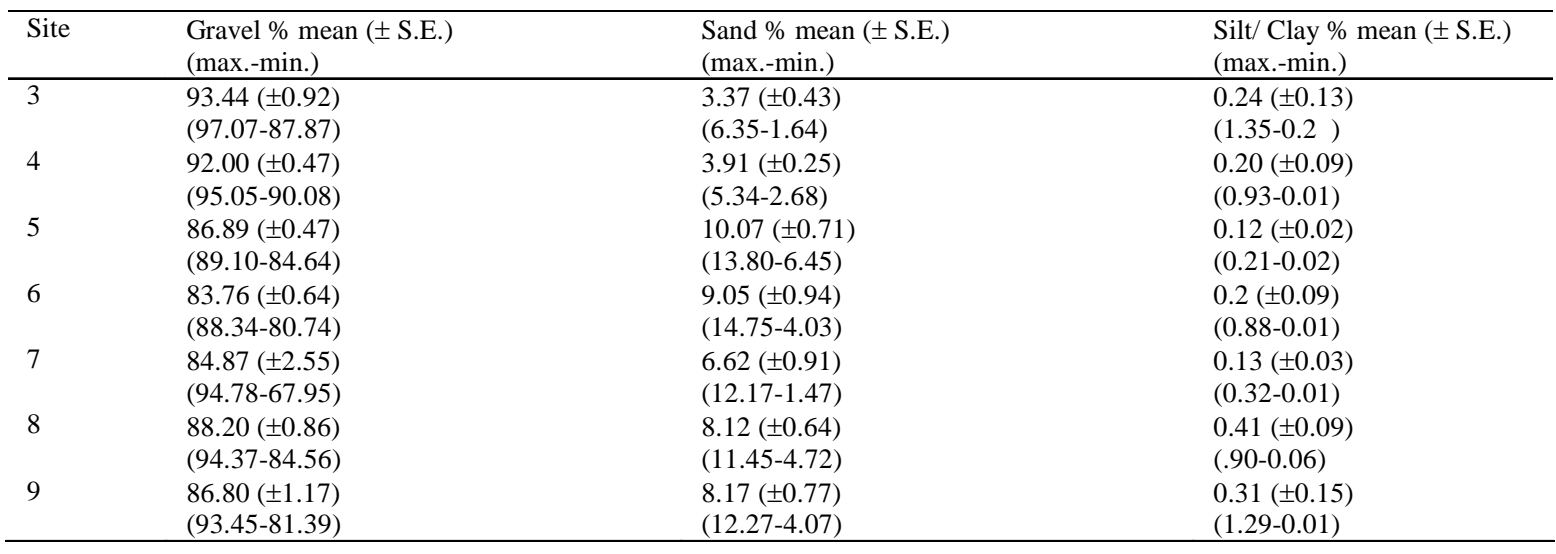

* Sites 1 and 2 did not have a natural distribution of grain- size and were respectively covered by crystallized salt and petrochemical residuals

Table 6: Results of non-parametric Kruscal-Wallis test for heavy metals content comparisons in Jafari Creek, north-west of Persian Gulf

\begin{tabular}{|c|c|c|c|c|c|}
\hline \multicolumn{3}{|c|}{$\begin{array}{l}\text { Source of variation } \\
\text { between surrounding and outer sites }\end{array}$} & \multicolumn{2}{|c|}{ Among nine sites } & \multirow[b]{2}{*}{$p$} \\
\hline Factor & df & $p$ & df & Chi-Square & \\
\hline $\mathrm{Hg}^{\mathrm{a}}$ & 1 & 0.33 & 8 & 9.10 & 0.33 \\
\hline $\mathrm{Cd}^{\mathrm{a}}$ & 1 & 0.18 & 8 & 3.23 & 0.92 \\
\hline $\mathrm{Pb}^{\mathrm{a}}$ & 1 & $0.00 *$ & 8 & 24.17 & $0.00 *$ \\
\hline $\mathrm{Ni}^{\mathrm{a}}$ & 1 & 0.62 & 8 & 16.00 & 0.42 \\
\hline
\end{tabular}

*Significant level $(p<0.05)$. ${ }^{a}$ Data transformed to $\log (\mathrm{x}+1)$ before analysis of variance

opportunistic polychaetes while crustaceans, bivalves and amphipods possessed lower abundances Consequently, the industrial activities in Jafari Creek have affected macroinvertebrate assemblages, which is indicated by decreased taxonomic richness, diversity and evenness followed by an increase in abundance of opportunistic taxa. The results are in agreement with the findings by Inglis and Kross (2000), who observed obvious macrofaunal changes caused by urbanization. Sediment characteristics may also have influenced the variations in community composition of invertebrate assemblages. The sites sampled in this study did not cover a wide range of sediment types. The dominant composition of sediments in general was fine materials with significant content of silt and clay, except in sites 1 and 2 . Fine materials with larger surface to volume ratio 


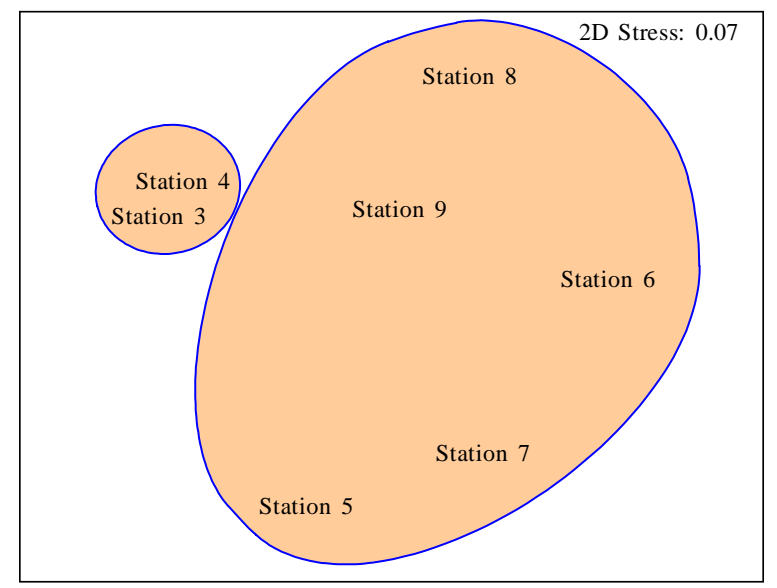

Fig. 4: nMDS ordination of sediment grain-size distribution in Jafari Creek, north-west of Persian Gulf. Sites 1 and 2 did not have a natural distribution of grain- size and were respectively covered by crystallized salt and petrochemical residuals.
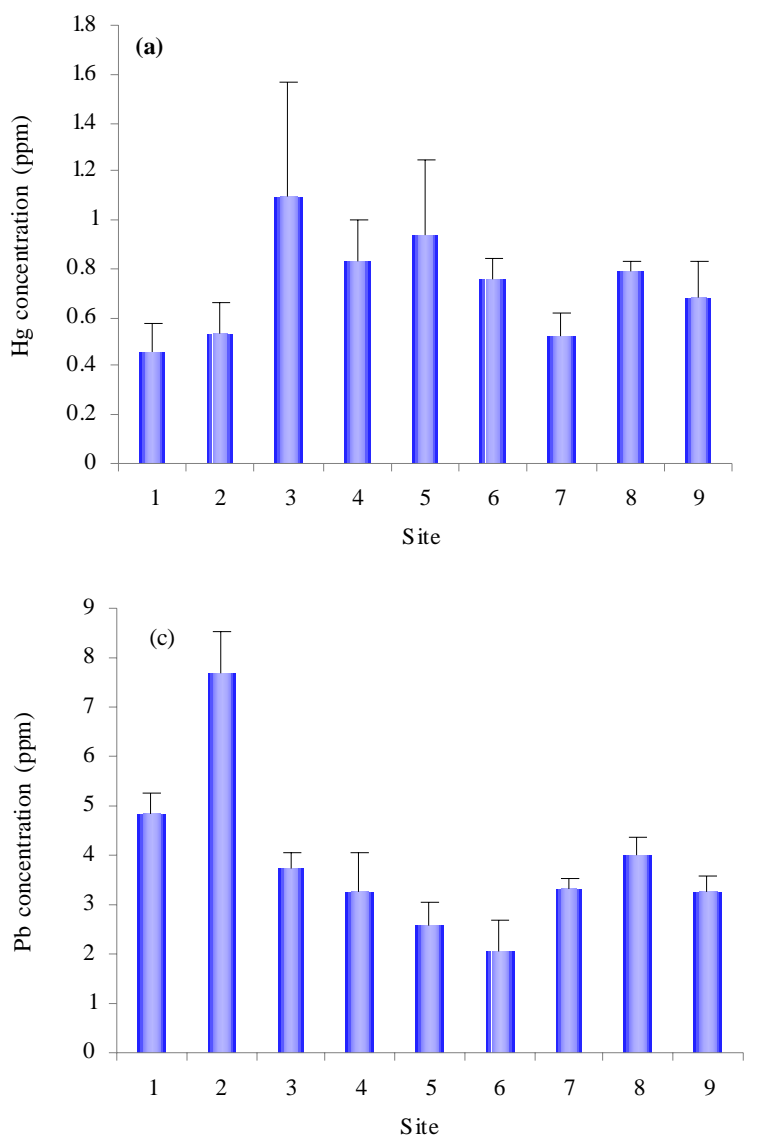

have greater potential to scavenge both inorganic and organic matters from the water column (Macfarlane and Booth, 2001; Burone et al., 2003; Silvia et al., 2006; Dehghan et al., 2008; Spruzne et al., 2008). The relative content of total organic matter across the study area was high and resulted in the appearance of abundant assemblages of deposit feeding polychaetes, but lacked filter- feeding bivalves and other molluscs common in the areas with fewer organic matters. Earlier studies have shown a general trend toward reduced faunal and trophic diversity, abundant short-lived opportunistic taxa with smaller body sizes, and fewer deep-dwelling species in contaminated sediments (Warwick and Clarke, 1993; Ward and Hutching, 1996; Rakocinski et al., 1997; Inglis and Kross, 2000). In the present study, macroinvertebrates showed both increased and decreased variability in the number of taxa in response to gradients in pollution, depending upon whether the groups involved were positively or negatively affected by sediment quality.
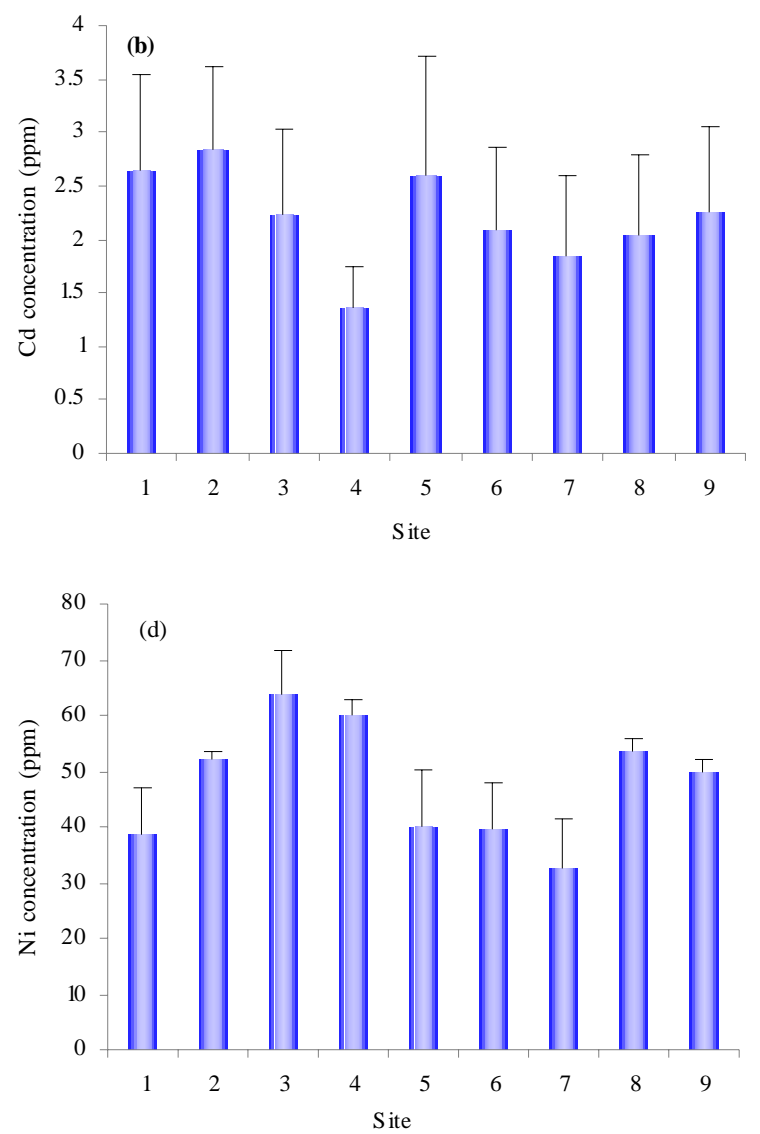

Fig. 5: Variation in the mean (S.E.) concentrations of: (a) Hg; (b) Cd; (c) Pb; (d) Ni in Jafari Creek, north-west of Persian Gulf 
N. Mooraki et al.

Table 7: Sediment quality guidelines and definitions from NOAA and environmental Canada guidelines and mean ( \pm S.E.), maximum, minimum for the studied heavy metals in Jafari creek, north-west of Persian Gulf. (mg/kg dry sediment).

\begin{tabular}{llllll}
\hline Element & ERL $^{1}$ & ERM $^{2}$ & ISQG(TEL) $^{3}$ & PEL $^{4}$ & $\begin{array}{l}\text { Present study } \\
\text { Mean }( \pm S . E .)\end{array}$ \\
\hline $\mathrm{Hg}$ & 0.2 & 0.7 & 0.1 & 0.7 & $0.732( \pm 0.072)(3.00-0.13)$ \\
$\mathrm{Cd}$ & 1.2 & 9.6 & 0.7 & 4.2 & $2.209( \pm 0.252)(6.34-0.01)$ \\
$\mathrm{Pb}$ & 47 & 220 & 30.2 & 112 & $3.865( \pm 0.283)(10.50-0.39)$ \\
$\mathrm{Ni}$ & 21 & 52 & 15.9 & 42.8 & $47.757( \pm 2.526)(93.50-2.10)$ \\
\hline
\end{tabular}

${ }^{1}$ ERL: Effects Range Low, ${ }^{2}$ ERM: Effects Range Medium, ${ }^{3}$ TEL: Threshold Effect Level (Maximum concentration at which no effect are observed),

${ }^{4}$ PEL: Probable Effect Level (Lower limit of the range of concentrations at which adverse effects are always observed).

Table 8: Contamination factor $\left(\mathrm{C}_{\mathrm{f}}\right)$, risk level of contaminants, contamination degree $\left(\mathrm{C}_{\mathrm{d}}\right)$ and pollution degree in Jafari Creek, north-west of Persian Gulf

\begin{tabular}{|c|c|c|c|c|}
\hline \multicolumn{4}{|c|}{ Contamination factor $\left(\mathrm{C}_{\mathrm{f}}\right.$ ) of Elements } & \multirow{2}{*}{$\begin{array}{l}\text { Contamination degree }\left(\mathrm{C}_{\mathrm{d}}\right) \\
\text { of the Jafari Creek }\end{array}$} \\
\hline $\mathrm{Hg}$ & $\mathrm{Cd}$ & $\mathrm{Pb}$ & $\mathrm{Ni}$ & \\
\hline \multirow[t]{2}{*}{$C_{f}=14.6$} & $\mathrm{C}_{\mathrm{f}}=1.264$ & $\mathrm{C}_{\mathrm{f}}=0.154$ & $C_{f}=0.682$ & \\
\hline & \multicolumn{2}{|c|}{ Risk level } & & $\mathrm{C}_{\mathrm{d}}=16.7$ \\
\hline $\mathrm{C}_{\mathrm{f}}>6$ & $1 ? \mathrm{C}_{\mathrm{f}}<3$ & $\mathrm{C}_{\mathrm{f}}<1$ & $\mathrm{C}_{\mathrm{f}}<1$ & Pollution degree \\
\hline Very high & Moderate & Unpolluted & Unpolluted & of the Jafari Creek \\
\hline
\end{tabular}

Polychaetes were positively associated with contaminated sediments in outer sites and exhibited greater abundance in comparison to bivalves, gastropods and crustaceans which showed a heterogeneous distribution in the study area, as shown by the results of SIMPER routine that average number of polychaetes per square meter in all sites (i. e. sites 3 to 9) was larger than that of bivalves and crustaceans. The overall changes in macroinvertebrate assemblages structure are frequently characterized by a move from domination of crustaceans and suspension- feeding molluscs to assemblages with proportionately greater abundance of deposit-feeding polychaetes such as Glycerids, Eunicids, Cossurids and Serpulids. Sites 1 and 2 with the most severe condition among the other sites were devoid of any macroinvertebrate individuals and sites 3 and 4, near the connective canal, with the highest mean value of mercury and nickel, respectively were dominated by Glycerids and Eunicids. Site 8 was dominated by large density of Venerid, bivalves, which may be due to the presence of artificially planted mangrove trees (Avecina marina). The presence of mangroves has probably facilitated the presence of higher densities of macroinvertebrates by water purification. Site 9 as the farthest site from the PETZONE boundaries was dominated by diverse macroinvertebrates and particularly molluscs. In terms of accumulation of inorganic matter in sediments, the spatial variation in the structure of fauna was concordant with similar, creek-wide variation in sediment concentrations of heavy metals. Concentrations of mercury and nickel in Jafari Creek were higher than acceptable quantities for unpolluted areas as suggested by NOAA (National Oceanic and Atmospheric Administration) and ISQGs (Interim Sediment Quality Guidelines) (Long et al., 1995). The contamination degree calculated for Jafari Creek (16.7) was higher than that measured for other Mahshahr Creeks as measured in an earlier study by Dehghan et al., 2008 showing contamination degree calculated as 16.22 for Ghannam, 10.35 for Dorag, 10.42 for Ghazale, 12.09 for Ahmady, 10.14 for Patil, 11.05 for Darvish, 11.41 for Zangy and 8.74 for Bihad. This suggests that the health of Jafari Creek has declined over time. It appears necessary to say that the contemporary assemblages of macroinvertebrates have been affected considerably by the presence of a variety of toxicants in the system during the period of exposure as it was shown in an earlier study by Landis et al. (1997).

\section{CONCLUSION}

In the present study, information about macrobenthic community assemblages and their relationship to environmental variables provides important baseline data which may be useful for assessing future environmental changes. The identification of a suite of 
environmental variables underlying the spatial variation in macroinvertebrate assemblages suggests that management should attempt to ensure minimal disturbance to their natural patterns of variation in environmental variables. The present study also showed that the ecological capacity of Jafari Creek, as a branch of Mahshahr Creeks, has largely been diminished due to industrialization. The current study also clearly showed an alteration in macroinvertebrate assemblage in response to industrial activities in the vicinity of PETZONE in Jafari Creek. In this regard, change in species composition of macrobenthos is suggested as a more reliable tool in determination of the status of alterations than the diversity indices alone.

\section{REFERENCES}

Aksu, A. E.; Yasar, D.; Uslu, O., (1997). Assessment of marine pollution in Izmir Bay: Heavy metal and organic compound concentrations in surficial sediments. Turk. Eng. Environ. Sci., 22 (5), 387-415 (29 pages).

Andrew, N. L.; Mapstone, B. D., (1987). Sampling and the description of spatial pattern in marine ecology. Oceanogr. Mar. Biol. Ann. Rev., 25 39-90 (52 pages).

Barry, J. P.; Dayton, P. K., (1991). Physical heterogeneity and the organization of marine communities. In: Kolasa, J., Pickett, S. T. A. (Eds.), Ecological Heterogeneity. Springer, New York, 270-320 (51 pages).

Bilyard, G. R., (1987). The value of benthic infauna in marine pollution monitoring studies. Mar. Pollut. Bull., 18 (11), 581585 (5 pages).

Buchman, M., (1999). NOAA screening quick reference tables. NOAA HAZMAT report 99-1, Seattle, WA, Coastal protection and restoration division, National Oceanic and Atmospheric Administration, 12

Burone, L.; Muniz, P.; Pires-Vanin, A. M. S.; Rodrigues, M., (2003). Spatial distribution of organic matter in the surface sediments of Ubatuba Bay (Southeastern- Brazil). Ann. Braz. Acad. Sci., 75 (1), 77-90 (14 pages).

CCME, (1999). Canadian quality guidelines publication. Canadian Council of Ministers of the Environmental, 1299: ISBN 1896997-34-1.

Chapman, M. G., (1998). Relationships between spatial patterns of benthic assemblages in a mangrove forest using different levels of taxonomic resolution. Mar. Biol. Prog. Ser., 162, 7178 (8 pages).

Chapman, M. G., (2002). Patterns of spatial and temporal variation of macrofauna under boulders in a sheltered boulder field. Austral Ecol., 27 (2), 211-228 (18 pages).

Clarke, K. R.; Warwick, R. M., (2001). Changes in marine communities: An approach to statistical analysis and interpretation. Plymouth Marine Laboratory, ISBN: 9781855311404.

Courtenay, G. C.; Gladstone, W.; Schreider, M., (2005). Assessing the response of estuarine intertidal assemblages to urbanized catchment discharge. Environ. Monit. Assess., 107 (1-3), 375398 (24 pages).
Currier, D. R.; Small, K. J., (2005). Macrobenthic community responses to long-term environmental change in an east Australian sub-tropical estuary. Estuar. Coast Shelf S., 63 (1-2) 315-331 (17 pages).

Dehghan, M. S.; Savari, A.; Parham, H.; Marammazy, J. G.; Papahn, F.; Sabzalizadeh S., (2008). Heavy metals contaminant evaluation in sediments of Khoure - Musa creeks, northwest of Persian gulf. Iran. J. Fish. Sci., 7 (2s), 137-156 (20 pages).

Dobson, M.; Frid, C., (1998). Ecology of aquatic systems, England, Longman, 208.

Eckman, J. E., (1996). Closing the larval loop: Linking larval ecology to the population dynamics of marine benthic invertebrates. J. Exp. Mar. Biol. Ecol., 200 (1-2), 207-237 (31 pages).

Folk, R. L., (1968). Petrology of sedimentary rocks. Hemphill publishing company, Austin, Texas. 182.

Gaston, G. R.; Nasci, J. C., (1988). Trophic structure of macrobenthic communities in the Calcasieu Estuary, Louisiana. Estuar. Coast., 11 (3), 201-211 (11 pages).

Glasby, G. J.; Fauchald, K., (2003). An information system for polychaete families and higher taxa. Verion 2:5.

Gray, J. S.; Aschan, M.; Carr, M. R.; Clarke, K. R.; Green, R. H.; Pearson, T. H.; Rosenberg, R.; Warwick, R. M., (1988). Analysis of community attributes of the benthic macrofauna of Frierfjord / Langesundfjord and in a mesocosm experiment. Mar. Ecol. Prog. Ser., 46, 151-165 (15 pages).

Hakanson, L., (1980). An ecological risk index for aquatic pollution control. A sedimentological approach. Water Res., 14 (8), 9751001 (27 pages).

Inglis, G. J.; Kross, J. E., (2000). Evidence for systematic changes in benthic fauna of tropical estuaries as a result of urbanization. Mar. Pollut. Bull., 41 (7-12), 367-376 (10 pages).

James, R. J.; Lincoln Smith, M. P.; Fairweather, P. G., (1995). Sieve mesh-Size and taxonomic resolution needed to describe natural spatial variation of marine macrofauna. Mar. Ecol. Prog. Ser., 118, 187-198 (12 pages).

Karbassi, A. R.; Nouri, J.; Mehrdadi, N., Ayaz, G. O., (2008). Flocculation of heavy metals during mixing of freshwater with Caspian Sea water. Environ. Geo., 53 (8), 1811-1816 (6 pages).

Kennish, M. J., (1991). Ecology of estuaries: Anthropogenic effects. CRC press , Taylor and Francis.

Kwon, Y. T.; Lee, C. W., (1998). Application of multiple ecological risk indices for the evaluation of heavy metal contamination in a coastal dredging area. Sci. Total Environ., 214 (1-3), 203210 (8 pages).

Landis, W. G.; Matthews, R. A.; Matthews, G. B., (1997). Design and analysis of multi species toxicity tests for pesticide registration. Ecol. Appl., 7 (4), 1111-1116 (6 pages).

Long, E. R.; Macdonald, D. D.; Smith, S. L.; Calder, F. D., (1995). Incidence of adverse biological effects within ranges of chemical concentrations in marine and estuarine sediments. Environ. Manage., 19 (1), 81-97 (17 pages).

Loring, D. H.; Rantala, R. T. T., (1992). Manual for geochemical analysis of marine sediments and suspended particulated matter. Earth Sci. Rev., 32, 235-283 (49 pages).

Macfarlane, G. R.; Booth, D. J., (2001). Estuarine macrobenthic community structure in the Hawkesbury river Australia: Relationships with sediment physicochemical and anthropogenic parameters. Environ. Monit. Assess., 72 (1), 51-78 (28 pages). 
Martin, J. W.; Davis, G. E., (2001). An updated classification of the recent crustacean. Natural history museum of LosAngeles county, Sccience Series 39.

Mikac, K. M.; Maher, W. A.; Jones, A. R., (2007). Do physicochemical sediment variables and their soft sediment macrofauna differ among microsize coastal lagoons with forested and urbanized catchments? Estuar. Coast. Shelf S., 72 (1-2), 308-318 (11 pages).

Morrisey, D. J.; Howitt, L.; Underwood, A. J.; Stark, J. S., (1992). Spatial variation in soft-sediment benthos. Mar. Ecol. Prog. Ser., 81, 197-204 (8 pages).

Morrisey, D. J.; Turner, S. J.; Mills, G. N.; Williamson, R. B.; Wise, B. E., (2003). Factors affecting the distribution of benthic macrofauna in estuaries contaminated by urban run-off. Mar. Environ. Res., 55 (2), 113-136 (24 pages).

Mucha, A. P.; Teresa, M.; Vasconcelos, S. D.; Bordalo, A. A., (2003). Macrobenthic community in the Douro estuary: Relations with trace metals and natural sediments characteristics. Environ. Pollut., 121 (2), 169-180 (12 pages).

Nabavy, S. B., (1992). Identification of marobenthos assemblages in Mahshahr Creeks and their trophic roles in the aquatic system. Ph.D. Thesis, Islamic Azad University, Science and Research Branch-Tehran, 130.

Nasr, S. M.; Okbah, M. A.; Kasem, S. M., (2006). Environmental assessment of heavy metal pollution in bottom sediments of Aden port, Yemen. Int. J. Oceans Oceanogr., 1 (1), 99-109 (11 pages).

Niyyati, M. F.; Maraghei, A., (2002). Raising the water level of Khor-e-Musa estuary using navigational lock, The changing coast Eurocoast/ EUCC, Porto-Portugal, Ed. EUROCOASTPortugal, ISBN 972-8558-09-0, 459-463 (5 pages).

Nouri, J.; Karbassi, A. R.; Mirkia, S., (2008). Environmental management of coastal regions in the Caspian Sea. Int. J. Environ. Sci. Tech., 5 (1), 43-52 (10 pages).

Parsamanesh, A., (1994). Hydrobiological survey of Khoozestan Province estuaries. Irainian Fisheries Reasearch Organization, 70 .

Ponder, W. F.; Clark, S. A.; Dallwitz, M. J., (2000). Fresh water and estuarine molluscs. An Interactive, Illustrated Key for New South Wales, CSIRO Publishing.

Rakocinski, C. F.; Brown, S. S.; Gaston, G. R.; Heard, R. W.; Walker, W. W.; Summers, J. K., (1997). Macrobenthic responses to natural and contaminant related gradients in northern Gulf of Mexico estuaries. Ecol. Appl., 7 (4), 1278-1298 (21 pages).
Raut, D.; Ganesh, T.; Murty, N. V. S. S.; Raman, A. V., (2005). Macrobenthos of kakinada Bay in the Godavari delta, east coast of India: Comparing decadal changes. Estuar. Coast. Shelf S., 62 (4), 609-620 (12 pages).

ROPME, (1999). Manual of oceanographic observation and pollutant analysis methods (MOOPAM). Regional organization for the protection of the marine environment, Kuwait, 483.

Silvia, G.; Costa, J. L.; De Almeida, P. R.; Costa, M. J., (2006). Structure and dynamics of a benthic invertebrate community in an intertidal area of the Tagus estuary, western Portugal: A six year data series. Hydrobiologia, 555 (1), 115-128 (14 pages).

Spruzen, F. L.; Richardson, A. M. M.; Woehler, E. J., (2008). Spatial variation of intertidal macroinvertebrates and environmental variables in Robbins passages wetlands, NW Tasmania. Hydrobiologia, 598 (1), 325-342 (28 pages).

Thrush, S. F., (1991). Spatial patterns in soft-bottom communities. Trends Ecol. Evol., 6 (3), 75-79 (5 pages).

Thrush, S. F.; Whitlatch, R. B.; Pridmore, R. D.; Hewitt, J. E.; Cummings, V. J.; Wilkinson, M. R., (1996). Scale-dependent recolonization: The role of sediment stability in a dynamic sand flat habitat. Ecology, 77 (98), 2472-2487 (16 pages).

Todd, J. A., (2001). Introduction to molluscan life habitats database. Department of paleontology, the natural history museum, Coromwell Road, London, UK.

Ward, T. J.; Hutchings, P. A., (1996). Effects of trace metals on infaunal species composition in polluted intertidal and subtidal marine sediments near a lead smelter, Spencer Gulf, South Australia. Mar. Ecol. Prog. Ser., 135, 123-135 (13 pages).

Warwick, R. M., (1988). The level of taxonomic discrimination required to detect pollution effects on marine benthic communities. Mar. Pollut. Bull., 19 (6), 259-268 (10 pages).

Warwick, R. M.; Clarke, K. R., (1993). Increased variability as symptom stress in marine communities. J. Experimen. Mar. Biol. Ecol., 172 (1-2), 215-226 (12 pages).

Ysebaert, T.; Herman, P. M. J.; (2002). Spatial and temporal variation in benthic macroinfauna and relationships with environmental variables in an estuarine, intertidal soft-sediment environment. Mar. Ecol. Prog. Ser., 244, 105-124 (20 pages).

Ysebaert, T.; Meire, P.; Herman, P. M. J.; Verbeek, H., (2002). Macrobenthic species response surfaces along estuarine gradients: Prediction by logistic regression. Mar. Ecol. Prog. Ser., 225, 79-95 (17 pages).

\section{AUTHOR (S) BIOSKETCHES}

Mooraki, N., Ph.D. candidate, Department of Natural Resources, Science and Research Branch, Islamic Azad University, Tehran, Iran. Email: nargess_mooraki@yahoo.com

Esmaeli Sari, A., Professor, Department of Fisheries, Faculty of Natural Resources and Marine Science, Tarbiat Modares University, Noor, Iran. Email: abbasesmailisarie@yahoo.com

Soltani, M., Professor, Department of Aquatic Animal Health, Faculty of Veterinary Medicine, University of Tehran, Tehran, Iran. Email: msoltani@yahoo.com

Valinassab, T., Associated professor, Iranian Fisheries Research Organization, Tehran, Iran. Email: t_valinassab@yahoo.com a tidal creek in relation to industrial activities. Int. J. Environ. Sci. Tech., 6 (4), 651-662. 